\title{
RATIONAL IDEAS HARUN NASUTION PERSPECTIVE OF ISLAMIC LAW
}

\author{
Oleh: Muh. Rasywan Syarif \\ E-mail:awan_elnaja@yahoo.co.id \\ Fakultas Syariah dan Hukum UIN Aluddin Makassar
}

\begin{abstract}
Abstrak
Gagasan pembaharuan hukum Islam lebih dipandang sebagai tantangan sekaligus ancaman yang perlu diwaspadai. Keadaan yang demikian ini hampir menjadi model pemikiran sebagian besar Muslim di Indonesia, yang tentu saja pada akhirnya memimbulkan kegelisahan bagi para penggiat pemikiran Islam, untuk berusaha melakukan rekonstruksi pemikiran, terutama bagi kalangan muda Muslim dari berbagai ormas Islam. Gesekan pemikiran, baik yang muncul dikalangan umat Islam maupun yang diimpor dari Barat, tentunya membawa pada wajah gerakan pemikiran Islam menjadi sangat variatif Obsesi Harun, yaitu ingin melihat ummat Islam Indonesia maju. Kemajuan tersebut menurutnya akan tercapai jika pemikiran umat Islam juga maju, dan pikiran maju tersebut bertitik tolak pada pandangan ideologi rasionalnya yang menurutnya sangat cocok dengan perkembangan dan tantangan kemajuan ketika itu. Atas dasar itulah Harun membawa pemikiran-pemikiran yang diintrodusir di IAIN, sehingga ketika memperkenalkan Islam, Harun mencoba menggunakan pendekatan filosofis dalam buah pikirannya seperti antara lain dalam buku Islam ditinjau dari Berbagai Aspeknya, Pembaharuan dalam Islam, Sejarah Pemikiran dan Gerakan, serta Islam Rasional, Gagasan dan Pemikiran Harun Nasution. Harun Nasution adalah seorang pembaharu pendidikan tinggi Islam di Indonesia, yang kontribusinya terhadap perkembangan pemikiran Hukum Islam di Indonesia, adalah hasil dari dialog antara dia dengan lingkungan.
\end{abstract}

Kata Kunci: Harun Nasution, Pemikiran dan Hukum Islam

\section{PENDAHULUAN}

Kemajuan zaman seiring dengan perkembangan pemikiran Islam Kontemporer mengakibatkan adanya berbagai perubahan dalam tatanan sosial masyarakat, baik yang menyangkut ideologi, politik, sosial, budaya dan sebagainya. Berbagai perubahan tersebut seolah-olah telah menjauhkan umat dari nilai-nilai keagamaan, yang pada akhirnya menimbulkan persoalan. Dari persoalan di atas akhirnya muncul satu persoalan lagi ketika adanya suatu kontrol sosial yang mampu mengendalikan gerakan perubahan yang mendasar tersebut. Sementara mapannya metodologi pemikiran Barat menuntut para 
pemikir Indonesia mampu bersaing secara ilmiah dengan menghasilkan metodologi pemikiran yang aplikatif sesuai dengan kebutuhan zaman.

Gagasan pembaharuan pemikiran Islam lebih dipandang sebagai tantangan sekaligus ancaman yang perlu diwaspadai. Keadaan yang demikian ini hampir menjadi model pemikiran sebagian besar Muslim di Indonesia, yang tentu saja pada akhirnya memimbulkan kegelisahan bagi para penggiat pemikiran Islam, untuk berusaha melakukan rekonstruksi pemikiran, terutama bagi kalangan muda Muslim dari berbagai ormas Islam. Gesekan pemikiran, baik yang muncul dikalangan umat Islam maupun yang diimpor dari Barat, tentunya membawa pada wajah gerakan pemikiran Islam menjadi sangat variatif. Munculnya Kencenderungan pemikiran yang berusaha mengadopsi metodologi pemikiran Barat, maupun dari pemikir Islam kontemporer yang muncul di Arab, tentu saja memunculkan reaksi dari kalangan Muslim konserfatif yang ingin selalu menjaga purifikasi ajaran Islam, sehingga nampak dipermukaan khususnya di Indonesia menimbulkan berbagai gerakan pemikiran baik yang melakukan rasionalisasi, purifikasi, neomodernisasi, bahkan sampai dengan sekularisasiliberasi. Salah satu tokoh yang akan dikaji dalam makalah ini yakni Harun Nasution.

Obsesi Harun, yaitu ingin melihat ummat Islam Indonesia maju. Kemajuan tersebut menurutnya akan tercapai jika pemikiran umat Islam juga maju, dan pikiran maju tersebut bertitik tolak pada pandangan ideologi rasionalnya yang menurutnya sangat cocok dengan perkembangan dan tantangan kemajuan ketika itu. Atas dasar itulah Harun membawa pemikiran-pemikiran yang diintrodusir di IAIN, sehingga ketika memperkenalkan Islam, Harun mencoba menggunakan pendekatan filosofis dalam buah pikirannya seperti antara lain dalam buku Islam ditinjau dari Berbagai Aspeknya, Pembaharuan dalam Islam, Sejarah Pemikiran dan Gerakan, serta Islam Rasional, Gagasan dan Pemikiran Harun Nasution.

Bukan seorang intelektual yang bebas dari kritik, itulah sosok Harun nasution yang dikenal sebagai intelektual islam di indonesia yang kontraversial. Salah satu tokoh yang mendukung dan pro dengan gagasan atau pemikiran filsafat harun nasution adalah Mukti Ali. Menurutnya, Harun nasution mampu mendampingi pendekatan agama secara normatif yang berpusat pada fikih dan filsafat menjadi ilmu yang harus dipahami umat Islam karena ilmu filsafat jarang dijamah pada waktu itu sehingga pemikiran kritis menjadi barang langka dalam umat Islam.

Nama lengkapnya adalah Prof. Dr. Harun Nasution. Ia dilahirkan pada tanggal 23 September 1919 di Pematang Siantar, Sumatera Utara. ${ }^{1}$ Ia berasal dari keluarga yang taat beragama. Ayahnya, Abd Jabbar Ahmad, selain sebagai seorang ulama, ia juga sebagai seorang pedagang yang sukses. Harun Nasution

${ }^{1}$ Lihat Zain Uchrowi dan Ahmadie Thaha, "Menyeru Pemikiran Rasional Mu'tazilah", dalam dalam Aqib Suminto, , Refleksi Pembaharuan Pemikiran Islam: 70 Tahun Harun Nasution (Cet.I; Jakarta: Lembaga Studi dan Filsafat, 1989), h. 5. 
adalah anak keempat dari lima bersaudara. Pada awal perkembangannya, oleh orang tuanya, ia dimasukkan ke sekolah Belanda, bukan sekolah Melayu. Kemungkinan hal itu disebabkan oleh orang tuanya telah memandang pendidikan agamanya sudah cukup diberikannya di rumah. Dalam usia 14 tahun, ia menamatkan pendidikannya di HIS (Hollandsch Indlandsche School). Dari sekolah inilah ia belajar bahasa Belanda dan ilmu pengetahuan umum.

Pada perkembangan selanjutnya, Harun Nasution bermaksud melanjutkan pendidikannya di MULO, tetapi orang tuanya memutuskan agar ia belajar di MIK (Modernet Islamictiche Kweekschool) di Bukit Tinggi, Sumatera Barat. Sekolah ini merupakan Sekolah Guru Menengah Pertama Swasta Modern milik Abd. Gafar Jambek, putera Syekh Jamil Jambek. Di sekolah ini ia belajar agama dengan pengantar bahasa Belanda, selama tiga tahun. Karena merasa tidak puas belajar di MIK, Harun Nasution bermaksud pindah ke sekolah Muhammadiyah di Solo. Namun orang tuanya mengirimnya ke Mekah, dengan harapan kelak ia akan menjadi guru di Masjid al-Har $\pm m$. Keinginan orang tuanya itu diturutinya dan ia pun berangkat ke Mekah untuk menunaikan ibadah haji dan menuntut ilmu. Karena di Mekah pun tidak kerasan, ia kemudian berangkat ke Mesir. Pada tahun 1939, ia terdaftar di Fakultas Ushuluddin Universitas al-Azhar.

Belajar di Universitas al-Azhar tidak membuatnya puas, meski nilai yang diperolehnya tinggi. Ia merasa belum tahu apa-apa, karena hanya dengan hafalan ia memperoleh nilai tersebut. Sambil kuliah di al-Azhar, ia juga kuliah di Universitas Amerika di Kairo hingga menyelesaikan studi sosialnya dengan gelar Sarjana Muda pada tahun 1952. ${ }^{2}$ Setelah itu, Harun Nasution memasuki dunia diplomat selama delapan tahun. Pada tahun 1960, ia kembali melanjutkan studinya, namun kuliahnya tersendat-sendat karena kekurangan biaya. Bersamaan dengan itu, ia mendapat tawaran beasiswa dari Prof. Dr. H. M. Rasjidi untuk belajar pada Institute of Islamic Studies Mc. Gill, Montreal, Kanada. ${ }^{3}$ Tawaran itu pun diterimanya.

Dalam perjalanan studinya di institut di atas, Harun Nasution menulis Pemikiran Negara Islam di Indonesia untuk tingkat magister. Sedangkan untuk program doktor, ia menulis disertasi yang berjudul Posisi Akal dalam Pemikiran Teologi Muhammad Abduh. ${ }^{4}$ Setelah menyelesaikan program doktornya, pada tahun 1969, Harun Nasution mendapat tawaran bekerja di IAIN Syarif Hidayatullah, Jakarta. Pada tahun 1971, ia menjabat sebagai Pembantu Rektor I. Namun karena Rektor Thaha Yahya menderita sakit lumpuh, akhirnya ia diusulkan untuk menduduki jabatan Rektor. Jabatan ini dipangkunya sejak tahun 1973 sampai $1984 .^{5}$

\footnotetext{
2Lihat ibid., h. 15.

${ }^{3}$ Lihat ibid., h. 24 dan lihat juga Catatan Akhir Pekan (CAP) Adian Husaini adalah kerjasama ke-124 Radio Dakta 107 FM dan www.hidayatullah.com

${ }^{4}$ Lihat ibid, h. 39.

${ }^{5}$ Lihat ibid., h. 41.
} 
Harun Nasution adalah figure sentral dalam semacam jaringan intelektual yang terbentuk di kawasan IAIN Ciputat semenjak paruh kedua dasawarsa 70an. Sentralitas Harun Nasution di dalam jaringan itu tentu saja banyak di topang oleh kapasitas intelektualnya, dan kemudian oleh kedudukan formalnya sebagai rector sekaligus salah seorang pengajar di IAIN. Dalam kapasitas terakhir ini, ia memegang beberapa mata kuliah terutama menyangkut sejarah perkembangan pemikiran yang terbukti menjadi salah satu sarana awal menuju pembentukan jaringan antara Harun Nasution dan mahasiswa-mahasiswanya. Setelah berhenti menjabat Rektor, Harun Nasution mengabdikan diri sebagai Direktur Program Pascasarjana IAIN Syarif Hidayatullah hingga akhir hayatnya. Ia wafat pada hari Jumat, 18 September 1998.

\section{METODE PENELITIAN}

Jenis penelitian ini tergolong kualitatif dengan menggunakan pendekatan penelitian pustaka (Library Research), yakni suatu peneltian dengan cara menuliskan, mengklarifikasi dan menjadikan data yang diperoleh dari berbagai sumber tertulis. Adapun metode pengumpulan data yakni mengguakan tehnik dokumen (studi pustaka), mengutip dan menganalisis data dengan tehnik dokumen dimaksudkan untuk mengumpulkan data terkait yang dimuat dalam dokumen-dokumen berupa buku-buku, jurnal dan hasil penelitian berupa skripsi, tesis, dan disertasi.

\section{HASIL \& PEMBAHASAN}

\section{A. Pemikiran Harun Nasution}

Harun Nasution (1919-1998) dikenal luas oleh kaum intelegensia Indonesia sebagai salah seorang ilmuan yang tekun mendalami berbagai bidang kajian keislaman antara lain ilmu kalam, falsafah, dan tasawuf. Karya karyanya baik dalam ilmu kalam, falsafah, dan tasawuf, itu umumnya bersifat deskripsi dengan pendekatan sejarah tentang berbagai aliran pemikiran yang berkembang di dunia Islam. Sekalipun fokus kajian Harun Nasution lebih banyak diarahkan kepada bidang-bidang ilmu kalam, falsafah dan tasawuf, namun ternyata ia juga memiliki minat yang besar dalam mengkaji dan mempunyai andil dalam pengembangan pendidikan tinggi Islam khususnya di Indonesia. ${ }^{6}$

Gerakan tersebut tidak pernah menyatakannya sebagai sebuah gerakan berorientasi kepada peningkatan kualitas dan pencerahan (enlightenment) kajian pendidikan tinggi Islam di Indonesia. Dikatakan sebagai suatu gerakan, karena Harun Nasution berhasil mengorganisir satu potensi besar yang menjadi faktor penentu perubahan studi Islam. Gerakan itu dimulai dari ruang kelas yang terbatas, kemudian berkembang menjadi gerakan yang cukup dahsyat. Debat-

\footnotetext{
${ }^{6}$ Yusril Ihza Mahendra, Islam dan Masalah Kenegaraan. dalam Abdul Halim (ed). Teologi Islam Rasional. Apresiasi terhadap Wacana dan Praksis Harun Nasution (Jakarta: Ciputat Press, Cetakan I, 2001), 183.
} 
debat kecil di ruang kelas tanpa disadari menjadi benih pendirian lembaga kajian Islam tingkat tinggi, yakni Program Pascasarjana IAIN di Indonesia. Ketika proyeksi rintisan terlembaga, maka gerakan ini menjadi semakin efektif dan sistematis. Atas dasar itu, Harun sangat tepat disebut sebagai perancang, pemikir perubahan dan pembaharu dalam tradisi akademik di lingkungan perguruan tinggi Islam Indonesia. ${ }^{7}$

Salah satu kontribusi Harun adalah pengenalan pendekatan Baru dalam studi Islam. Dikatakan baru karena pendekatan sebelumnya didominasi oleh pendekatan tradisional yaitu fikih sentris-doktriner-anti kritisisme. ${ }^{8}$ Pendekatan ini tradisional ini sering juga disebut pendekatan normatif. Pendekatan yang digunakan Harun memang pendekatan filsafat dengan titik tekan pada rasionalisme. Kedudukan filsafat merupakan salah satu dari aspek Islam yang sejajar kedudukannya dengan aspek hukum dan aspek lainnya. Ijtihad tidak hanya dalam bidang fikih tetapi juga diaspek lainnya seperti filsafat.

\section{Peranan akal}

Bukankah secara kebetulan bila Harun Nasution memilih problematika akal dalam system teologi Muhammad Abduh sebagai bahan kajian disertasinya di Universitas McGill, Montreal, Kanada. Besar kecilnya peranan akal dalam system teologi suatu aliran sangat menentukan dinamis atau tidaknya pemahaman seseorang tentang ajaran Islam. Berkenaan dengan akal ini, Harun Nasution menulis demikian, "Akal melambangkan kekuatan manusia. Karena akallah, manusia mempunyai kesanggupan untuk menaklukkan kekuatan makhluk lain sekitarnya. Bertambah tinggi akal manusia, bertambah tinggilah kesanggupanya untuk mengalahkan makhluk lain. Bertambah lemah kekuatan akal manusia, bertambah rendah pulalah kesanggupannya menghadapi kekuatan-kekuatan lain tersebut.

Sebagai seorang pemikir dan pembaru di Indonesia, Harun Nasution telah membuka cakrawala berpikir umat Islam untuk tidak berpandangan sempit dan tradisional. Menurutnya, pandangan sempit dan tradisionalisme tidak dapat berjalan sejajar dengan modernisasi, bahkan bertentangan dengannya. 9 Usahanya dalam mengembangkan sikap inklusivisme dalam Islam, menimbulkan kontra bagi mereka yang berpikir tradisional.

Dalam mengemukakan paham rasionalnya, Harun Nasution menganggap akal sebagai lambang kekuatan manusia. ${ }^{10}$ Islam memberikan kedudukan yang tinggi pada akal, sebab manusia memiliki kemampuan untuk

\footnotetext{
7 Said Aqil al Munawwar, Membangun Tradisi Kajian Islam: Mengikuti Jejak Harun Nasution. dalam Abdul Halim (ed) Teologi Islam Rasional, Apresiasi terhadap Wacana dan Praksis Nasution (Jakarta: Ciputat Press, 2001), 35.

${ }^{8}$ Bukan Memperbaharui Ayat tapi penafsiran dalam panji masyarakat, No.743,1993,h.26 dan lihat selanjutnya di Nurisman, Pemikiran filsafat Islam Harun Nasution,2012.h.3

${ }^{9}$ Lihat Harun Nasution, Islam Rasional: Gagasan dan Pemikiran (Cet.IV; Bandung: Mizan, 1996), h. 157.

${ }^{10}$ Lihat Harun Nasution, Akal dan Wahyu dalam Islam (Jakarta: UI-Press, 1983), h. 80.
} 
mempertimbangkan baik-buruknya perbuatan, dapat menentukan kehendaknya sendiri dan mewujudkan apa yang dikehendakinya. Manusia adalah makhluk yang dinamis lagi aktif dan bukan makhluk pasif, yang menyerahkan masa depannya kepada nasib dan perkembangan zaman.11

Dalam ajaran Islam, pemakaian akal tidaklah diberikan kebebasan mutlak, sehingga pemikir Islam dapat melanggar garis-garis yang telah ditentukan Alquran dan Hadis, namun tidak pula diikat dengan ketat. Bagi Harun Nasution, kata-kata rasional, rasionalisme, dan rasionalis dalam Islam harus dilepaskan dari arti kata sebenarnya, yaitu percaya kepada rasio semata-mata dan tidak mengindahkan wahyu. ${ }^{12}$

Jika suatu aliran memberikan kekuatan yang besar kepada akal aliran tersebut bercorak rasional dan yang bercorak rasionanl itu ditampilkan oleh Mu'tazilah, maka Harun sering dituduh sebagai "Neo Mu'tazilah"13 di Indonesia.

Bagi Harun wahyu tidak pernah bertentang dengan akal. Di samping itu pemakaian kata-kata rasional, rasionalisme dan rasionalis dalam Islam harus dilepaskan dari arti sebenarnya yaitu percaya kepada rasio semata-mata dan tidak mengindahkan wahyu atau membuat akal lebih tinggi dari pada wahyu sehingga wahyu dapat dibatalkan oleh akal. Akal tetap tunduk kepada teks wahyu yang mutlak benar. Akal dipakai hanya untuk menginterpretasi teks wahyu. Menurut Harun untuk mengadakan pembaharuan dalam Islam harus dibedakan antara ajaran yang qath'iy dan zhanniy, antara absolut dan relatif. Ajaran absolut tidak bisa dikembangkan sesuai dengan perkembangan zaman. ${ }^{14}$ Perkembangan zaman yang harus tunduk kepada ajaran absolut. Persoalan yag tidak absolut berarti tidak qath'iy al-dalalah melainkan zanniy al-dalalah. Di sini wilayah pembahruan pemikiran yang penafsirannya dapat disesuaikan dengan perkembangan zaman. ${ }^{15}$

Itulah sebabnya Harun Nasution menyodorkan pendekatan vertikal terhadap perbedaan pendapat tentang teks wahyu yang zanniy al-dalalah, bukan pendekatan horisontal, sebab akan melahirkan perbedaan-perbedaan yang besar dan akan muncul kesimpulan bahwa salah satu dari ijtihad itu yang benar, sedangkan yang lain salah dan bukan Islam. Akan tetapi dengan pendekatan

\footnotetext{
${ }^{11}$ Lihat Harun Nasution, Islam Rasional,., h. 144.

${ }^{12}$ Lihat Harun Nasutin, Akal dan Wahyu, h. 101.

${ }^{13}$ Lihat M. Yunan Yusuf, "Mengenal Harun Nasution melalui Tulisannya, dalam Refleksi... op.cit., h. 132.

${ }^{14}$ Harun mencontohkan bahwa soal riba dan khamar itu haram, termasuk bahwa Tuhan itu ada dan Maha Esa. Itu adalah ajaran absulut yang tidak bisa dihilangkan sepanjang zaman. Refleksi pembaharuan..., op.cit., h. 54 .

${ }^{15}$ Kebebasan akal hanya terikat pada ajaran-ajaran absolut dalam kedua sumber utama ajaran Islam. Masalah zhanniy al-dalalah dan zhanni al-wurud, maka penafsirannya bisa bercorak majasi dan metaforis dari teks ajaran dasar yang terdapat dalam kedua ajaran itu. Dengan kata lain dalam pemikiran rasional agamis diusahakan pemahaman ayat dan hadis sedemikian hingga sesuai dengan pendapat akal dengan sarat tidak bertentangan dengan ajaran absolut. Harun Nasution, Islam rasional, op.cit., h.9.
} 
vertikal, karena sumber dari perbedaan pendapat tersebut adalah sama yakni Alquran dan Hadis maka semua itu tetap berada dalam kebenaran meskipun berbeda dalam penafsiran dan perincian. ${ }^{16}$

Harun Nasution menilai bahwa dalam pemikiran Islam, baik dalam bidang filsafat, teologi, dan fikih, akal tidak pernah membatalkan wahyu. Akal tetap tunduk kepada teks wahyu dan sekali-kali tidak untuk menentang wahyu. Akal hanya memberi interpretasi terhadap teks wahyu, sesuai dengan kecenderungan dan kesanggupan pemberi interpretasi.

Dalam sejarah pemikiran Islam, yang dipertentangkan sesungguhnya bukan akal dan wahyu oleh para teolog, filosof, dan fuqaha'. Pertentangan mereka mengenai penafsiran tertentu dari teks wahyu dengan penafsiran lain dari teks wahyu yang sama. Dengan kata lain, yang bertentangan adalah pendapat ulama tertentu dengan pendapat ulama lainnya mengenai penafsiran terhadap ayatayat Alquran dan teks Hadis. ${ }^{17}$

Menurut Harun Nasution, ijtihad merupakan salah satu unsur terpenting dalam ajaran Islam, bahkan menjadi kunci dinamika Islam. ${ }^{18}$ Sejarah telah membuktikan bahwa sejak pintu ijtihad tertutup oleh ulama-ulama pertengahan abad IV H, Islam mengalami kemunduran dalam segala bidang. Namun, bagi orang Eropa yang mengambil alih jiwa ijtihad yang rasional mengalami kemajuan yang sangat pesat. Begitu pentingnya ijtihad tersebut, ia menempatkannya sebagai sumber ajaran Islam yang ketiga setelah Alquran dan Hadis. ${ }^{19}$

Bagi Harun Nasution, masyarakat Indonesia masih banyak dipengaruhi oleh teologi corak tradisional. Penghargaan terhadap akal sebagai anugerah Tuhan belum cukup memadai. Karena paham qadha dan qadar masih banyak terdapat di kalangan masyarakat. ${ }^{20}$ Karenanya, yang terpenting dalam pembangunan agama adalah upaya mengubah sikap mental tradisional menjadi sikap mental rasional. ${ }^{21}$ Sikap yang disebutkan terakhir inilah yang dapat menumbuhkan semangat intelektualisme, sehingga berbagai persoalan yang timbul akan mudah dihadapi dan diantisipasi.

Tema Islam agama rasional dan dinamis sangat kuat bergema dalam tulisantulisan Harun Nasution, terutama dalam buku Akal dan Wahyu dalam Islam, Teologi Islam: Aliran-aliran, Sejarah, Analisa Perbandingan, dan Muhammad

\footnotetext{
16Lihat M.Yunan Yusuf, op.cit., h. 130.

${ }^{17}$ Lihat Harun Nasutin, Akal dan Wahyu., h. 102.

${ }^{18}$ Harun Nasution, "Ijtihad Sumber Ketiga Ajaran Islam", dalam Haidar Baqir dan Syafiq Basri (ed), Ijtihad dalam Sorotan (Cet. I; Bandung: Mizan, 1988), h. 113.

${ }^{19}$ Ibid., h. 116.

${ }^{20}$ Harun Nasution, Islam Rasional, op.cit., h. 145.

${ }^{21}$ Faham teologi orang indonesia adalah jabariah. Hal ini dapat dibuktikan dengan kata-kata qadha dan qadar. Jika dikaitkan dengan kehidupan maka orang indonesia statis sehingga menurut sejarah bung Karno pernah merintis untuk merubah dan meyakinkan umat islam di indonesia untuk beralih dari paham Jabariyah ke Qadariyyah. Lihat Harun Nasution, Teologi Indonesia harus Qadariah,h.12 .
} 
Abduh dan Teologi Rasional Muhammad Abduh. Dalam ajaran Islam, akal mempunyai kedudukan tinggi dan banyak di pakai, bukan dalam perkembangan ilmu pengetahuan dan kebudayaan saja, tetapi juga dalam perkembangan ajaran-ajaran keagamaan islam sendiri. Pemakaian akal dalam islam di perintahkan Al-Quran sendiri. Bukankah tidak ada dasarnya kalau ada penulis-pennulis, baik di kalangan islam sendiri maupun di kalangan non-islam, yang berpendapat bahwa Islam adalah agama rasional.

\section{Pembaharuan Teologi}

Pembaharuan teologi, yang menjadi predikat Harun Nasution, pada dasarnya dibangun atas asumsi bahwa keterbelakangan dan kemunduran umat Islam Indonesia (juga dimana saja) adalah disebabkan "ada yang salah" pada teologi mereka. Pandangan ini, (Muhammad Abduh, Rasyid Ridha, Al-Afghani, Sayid Amer Ali, dan lainya) yang memandang perlu untuk kembali pada teologi Islam yang sejati. Retorika ini mengandung pengertian bahwa umat Islam dengan teologi fatalistic, irasional, pre-determinisme serta penyerahan nasib telah membawa nasib mereka menuju kesengsaraan dan keterbelakangan. Dengan demikian, jika hendak mengubah nasib umat islam, menurut Harun Nasution, umat Islam hendaklah mengubah teologi mereka menuju teologi yang berwatak free-will, rasional, serta mandiri. Tidak heran jika teori modernisasi ini selanjutnya menemukan teologi dalam khasanah Islam klasik sendiri yakni teologi Mu'tazilah.

\section{Hubungan akal dan wahyu}

Wahyu bersal dari kata al-wahy (الوحى), dan al-wahy adalah kata asli Arab dan bukan kata pinjaman dari bahasa asing. Kata itu berarti suara, api dan kecepatan. Al-wahy selanjutnya mengandung arti pemberitahuan secara sembunyi dan dengan cepat. Tetapi kata itu lebih dikenal dalam arti "apa yang disampaikan Tuhan kepada Nabi-Nabi".

Wahyu adalah tanda keadilan Allah, kebaikan dan kewajiban Allah terhadap manusia, maka dari sudut manusia, Iman adalah tanggapan manusia mengenai wahyu Tuhan. Karena itu, wahyu dan iman merupakan dua entitas yang saling menanggapi. Wahyu Tuhan baru benar-benar mempunyai arti jika ditanggapi oleh Iman manusia. Pandangan Harun tentang perlunya berfikir rasional dalam memahami agama, pada tataran tertentu mempertanyakan kembali tentang konsep dan argumen dibalik paham dan praktek keagamaan yang selama ini taken for granted. Di samping itu keinginan Harun untuk mengajarkan agar umat Islam terbiasa dengan perbedaan pendapat bahwa ternyata Islam mempunyai bermacam-macam aspek, sering berhadapan dengan paham keislaman atau pemahaman keislaman yang belum siap menerima keragaman paham keagamaan paham keagamaan yang berkembang

Penjelasan tentang cara terjadinya komunikasi antara Tuhan dan Nabi-Nabi, diberikan oleh Al-Qur'an sendiri. Salah satu ayat dalam surah Al-Syura menjelaskan: 
“Dan tidak mungkin bagi seorang manusiapun bahwa Allah berkata-kata dengan Dia kecuali dengan perantaraan wahyu atau dibelakang tabir atau dengan mengutus seorang utusan (malaikat) lalu diwahyukan kepadanya dengan seizin-Nya apa yang Dia kehendaki. Sesungguhnya Dia Maha Tinggi lagi Maha Bijaksana." (Q. S. Asy-Syuura 51)

Wahyu dalam bentuk pertama kali kelihatannya adalah pengertian atau pengetahuan yang tiba-tiba dirasakan seseorang timbul dalam dirinya, timbul dengan tiba-tiba sebagai suatu cahaya yang menerangi jiwanya. Kedua, wahyu berupa pengalaman dan penglihatan dalam keadaan tidur atau dalam keadaan trance, ru'yat atau kasyf (vision). Ketiga, wahyu dalam bentuk yang diberikan melalui utusan atau malaikat, yaitu Jibril, dan wahyu serupa ini disampaikan dalam bentuk kata-kata.

Sabda Tuhan yang disampaikan kepada Nabi Muhammad SAW. Adalah dalam bentuk ketiga, dan itu ditegaskan oleh ayat-ayat Al-Qur'an. Dalam surah Al-Syu'ara dijelaskan:

"Dan Sesungguhnya Al Quran ini benar-benar diturunkan oleh Tuhan semesta alam, - Dia dibawa turun oleh Ar-Ruh Al-Amin (Jibril), - ke dalam hatimu (Muhammad) agar kamu menjadi salah seorang di antara orangorang yang memberi peringatan, - dengan bahasa Arab yang jelas." (Q. S. Asy-syuara; 192-195)

Filosof yang mempunyai akal perolehan lebih rendah dari Nabi yang memperoleh akal material atau hads. Dengan lain kata, filosof tidak bisa menjadi Nabi. Nabi tetaplah orang pilihan Tuhan. Selanjutnya filosof hanya dapat menerima ilham, wahyu hanya diberikan kepada Nabi-nabi. Menurut ajaran tassawuf, komunikasi dengan Tuhan dapat dilakukan melalui daya rasa manusia yang berpusat dihati sanubari. Kalau filosof dalam Islam mempertajam daya pikir atau akalnya dengan memusatkan perhatian pada hal-hal yang bersifat murni abstrak, sufi mempertajam daya rasa atau kalbunya dengun menjauhi hidup kematerian dan memusatkan perhatian dan usaha pada pensucian jiwa.

AI-Farabi, filosof Islam yang hidup di abad kesembilan dan kesepuluh Masehi, telah juga membawa konsep imateri berubah menjadi materi ini dalam falsafat penciptaan alam semesta yang dikenaI dengan falsafat emanasi atau pancaran sebagai telah dijelaskan sebelumnya. Tuhan memancarkan akal-akal yang bersifat abstrak murni dan akal seperti dilihat di atas adalah daya pikir. Salah satu fokus pemikiran Harun Nasution adalah hubungan antara akal dan wahyu. Ia menjelaskan bahwa hubungan wahyu dan akal memang menimbulkan pertanyaan, tetapi keduanya tidak bertentangan. Akal mempunyai kedudukan yang tinggi dalam Al-Quran. Orang yang beriman tidak perlu menerima bahwa wahyu sudah mengandung segala-galanya. Wahyu bahkan tidak menjelaskan semua permasalahan keagamaan.

Dalam pemikiran Islam, baik di bidang filsafat dan ilmu kalam, apalagi di bidang ilmu fiqih, akal tidak pernah membatalkan wahyu. Akal tetap tunduk 
kepada teks wahyu. Teks wahyu tetap di anggap benar. Akal hanya memberi interpretasi terhadap teks wahyu sesuai dengan kecenderungan dan kesanggupan pemberi interpretasi. Yang dipertentangkan dalam sejarah pemikiran Islam sebenarnya bukan akal dengan wahyu, tetapi penafsiran tertentu dari teks wahyu dengan penafsiran lain dari teks wahyu itu juga. Jadi, yang bertentangan sebenarnya dalam islam adalah pendapat akal ulama tertentu dengan pendapat akal ulama lain.

\section{Ajaran Dasar dan Nondasar}

Yang dimaksud dengan ajaran dasar ialah ajaran yang bersifat absolut; suatu ajaran yang tidak mengalami perubahan. Ajaran nondasar ialah ajaran yang bersifat relatif, tersentuh pemikiran, dan mengalami perubahan sesuai dengan kondisi sosial masyarakat. Menurut Harun Nasution, jika ingin melakukan pembaruan, mesti harus dibedakan antara yang qat'iy dan zhanniy sebagai kuncinya. ${ }^{22}$ Dalam ajaran Islam, ada hal-hal yang bersifat mutlak dan tidak dapat berubah. Semetara itu, ada pula hal-hal yang tidak bersifat mutlak, seperti penafsiran atau interpretasi dari yang bersifat mutlak tadi, dan inilah yang dapat berubah. ${ }^{23}$

Selama ini, umat Islam hanya mengenal dua macam nas, yaitu qat'iy dan zhanniy, baik menurut wur-d (sumber) maupun dallah (makna)-nya. Padahal menurut Harun Nasution, di samping wur-d dan dallah nas, bisa juga dilihat dari sudut pelaksanaan-nya. ${ }^{24}$ Dalam buku fikih, hukum yang qath'iy hanya sedikit jumlahnya. Terdapat bagian tertentu dalam Alquran dan Hadis, yang tidak dapat disesuaikan dengan zaman, dan itulah ajaran yang absolut. Sebagai contoh, Harun Nasution menunjuk keharaman riba. Haramnya riba bersifat absolut, tidak bisa disesuaikan dengan zaman. Jika ada yang berpendapat bahwa riba tidak haram lagi karena sudah banyak yang menjalankannya pada masa kini, maka pendapat semacam itu tidak dapat diterima. ${ }^{25}$

22Zain Uchrowi dan Ahmadie Thaha, "Yang Absolut dan Relatif", dalam Aqib Suminto, h. 53.

${ }^{23}$ Lihat Harun Nasution, Islam Ditinjau dari Berbagai Aspeknya (Cet.VI; Jakarta: UI-Press, 1986), Jilid II, h. 93.

${ }^{24}$ Lihat Zain Uchrowi dan Ahmadie Thaha, "Yang Absolut dan Relatif", dalam Aqib Suminto, et al., op. cit., h. 54. Penjelasan mengenai ajaran yang qat'iy dan zhanniy, dipertegas oleh Jalaluddin Rahman sebagai berikut. Qat'iy terbagi atas: (1) qat'iy al-wurd, yakni ajaran yang pasti sumber kedatangannya, seperti Alquran dan Hadis mutawatir; (2) $q a^{-}$'iy al-dallah, yakni ajaran yang pasti maknanya karena hanya memiliki satu arti; (3) qat'iy al-tanfh, yakni ajaran yag mesti diberlakukan dan bila tidak dilaksanakan, maka seseorang terbilang melakukan pelanggaran. Demikian halnya dengan zhanni terbagi atas: (1) zhanniy al-wurd, yakni ajaran yang tidak dipastikan kedatangannya, seperti hadis; (2) zhanniy al-dallah, yakni ajaran yang tidak pasti maknanya karena makna yang dikandungnya mempunyai arti lebih dari satu; (3) zhanniy al-tanfh, yakni ajaran yang tidak mesti diberlakukan, seperti masalah waris. Lihat selengkapnya Jalaluddin Rahman, Islam dalam Perspektif Pemikiran Kontemporer (Cet.I; Ujungpandang: PT. Umitoha Ukhuwah Grafika, 1997), h. 2-3.

${ }^{25}$ Lihat Zain Uchrowi dan Ahmadie Thaha, "Yang Absolut dan Relatif", dalam Aqib Suminto, h. 8 
Persoalan yang relatif (zhanniy al-dalalah) menurut Harun Nasution bisa disesuaikan dengan perkembangan zaman. Sebagai contoh, Alquran menyebut zhulumat al-tsalats (tiga kegelapan) yang dihadapi anak dalam kandungan ibunya. Pada tafsir lama, arti tiga kegelapan tersebut adalah rahim, perut, dan tulang belakang. Tafsiran seperti ini tidak masuk akal, karena tulang belakang dan perut hanya satu. Untuk ayat tersebut, sebaiknya ditelusuri melalui embriologi. Oleh karena itu, keterangan seorang dokter yang menafsirkan zhulumat al-tsalats yang terdiri atas rahim, omnion, dan corion dapat diterima. ${ }^{26}$

Di bidang akidah ditemukan pula absolut dan relatif. Sebagai contoh yang relatif, Harun Nasution menunjuk point keenam dari rukun iman, percaya kepada qadha dan qadar. Rukun ini membawa masyarakat kepada sikap pasif dan pasrah, padahal dunia modern menghendaki keaktifan dan dinamika. Karena hadis yang menunjukkan poin tersebut berstatus zhanniy al-wurud, maka sebaiknya point itu diabaikan. Menurutnya, rukun iman hanya lima, sesuai dengan ketentuan dalam Alquran. Dalam Alquran, kata qadhaina dan qaddarna memang disebutkan, tetapi tidak menunjuk kepada rukun iman.

\section{Pembaruan dalam Pendidikan di Indonesia}

Gagasan pembaruan pendidikan yang ditawarkan Harun Nasution bermula pada saat ia memangku jabatan sebagai Rektor IAIN Syarif Hidayatullah, Jakarta. Salah satu gagasannya adalah perubahan kurikulum, yang disebut sebagai kurikulum tahun 1973. Dalam kurikulum ini, selain ilmu agama, filsafat, tasawuf, ilmu kalam, sosiologi, dan metodologi riset dimasukkan sebagai mata kuliah wajib. ${ }^{27}$ Tujuannya adalah untuk mengubah cakrawala berpikir mahasiswa.

Dimasukkannya mata kuliah PIA (Pengantar Ilmu Agama) dan filsafat, dimaksudkan untuk menjadikan mahasiswa tidak hanya berpikir normatif saja, tetapi juga berpikir rasional. Jika kedua mata kuliah tidak ada, maka mahasiswa akan kembali kepada pemikiran yang normatif seperti masa lampau. Akibatnya, Islam tidak akan maju. 28

Menurut Harun Nasution, pandangan sempit yang berkembang pada masyarakat dewasa ini, harus diperluas dengan mengubah pendidikan agama yang selama ini hanya dipusatkan pada ajaran ibadah dan fikih. Dalam pendidikan agama tersebut, harus ditambah dan diperbanyak dengan mata kuliah mengenai dasar-dasar hukum Islam, perbandingan mazhab, teologi dengan aliran-aliran yang terdapat di dalamnya, filsafat, mistisisme, sejarahkebudayaan Islam. Dengan memperluas pandangan ini, banyak hal yang selama ini dianggap bertentangan dengan Islam, ternyata pada akhirnya tidak demikian. ${ }^{29}$

\footnotetext{
26Lihat Zain Uchrowi., h. 55.

${ }^{27}$ Lihat Zain Uchrowi dan Ahmadie Thaha, "Mulai Berkutat di Ciputat", dalam Aqib Suminto, et al., op. cit., h. 41.

${ }^{28}$ Lihat ibid., h. 43.

${ }^{29}$ Lihat Harun Nasution, Islam Rasional, h. 166.
} 
Bagi Harun Nasution, yang diperlukan oleh masyarakat Indonesia adalah pendidikan agama, bukan pengajaran agama. Pendidikan agama dalam pendidikan dan perguruan di Indonesia, bukan bertujuan menghasilkan siswa atau mahasiswa yang berjiwa agama, tetapi siswa atau mahasiswa yang berpengetahuan agama. ${ }^{30}$ Selanjutnya, tujuan pendidikan agama, seharusnya bukanlah pengajaran pengetahuan agama dan praktik-praktik ibadah sematamata, tetapi yang terpenting ialah pendidikan moral. Untuk tingkat TK, SD, SLTP, dan SLTA, pendidikan morallah yang diutamakan. Sedangkan untuk tingkat perguruan tinggi, pendidikan moral tetap dilanjutkan, tetapi penekanannya pada pendidikan spritual dan paham rasional tentang ajaranajaran agama. ${ }^{31}$

Selain itu, usaha Harun Nasution untuk mengangkat lembaga pendidikan Islam di IAIN sangat luar biasa. Hal ini dapat dilihat dengan gebrakan yang ia lakukan dengan mempelopori berdirinya Program Pacasarjana. Maksud pendirian tersebut ialah untuk mencetak pemimpin umat Islam masa depan, yaitu pemimpin yang rasional, mengerti Islam secara komprehensif, serta tahu tentang agama dan filsafat.

\section{B. Kritik Pemikiran Harun Nasution}

Faktor ruang dan waktu mempunyai pengaruh yang besar terhadap produk pemikiran tertentu karena pemikiran itu tidak muncul dari ruang hampa. Sejalan dengan sepak terjang pemikiran Harun Nasution ternyata tidak serta merta diterima dalam realitas dengan pengkaliaman cacat epistemologis diantaranya: Dampak dari pemikiran Harun menurut Prof. HM.Rasjidi ${ }^{2}$ menuduh harun telah mengacaukan dan meragukan keimanan umat Islam di Indonesia bahkan dianggap sebagai agen orentalis. Produk pemikiran harun dinilai dengan pendekatan fiqh sentris (legal God) sehingga Rasjidi mengkirtiknya dari persfektif Rasionalitas dengan kerangka Immanuel Kant dalam pemikiran keislamannya. Rasjidi mengatakan:

Jika pendapat Harun Nasution diikuti maka orang tidak perlu mengikuti agama karena akalnya sudah cukup untuk dijadikan sebagai pedoman hidupnya dan pedoman bagi tindakan yang dikerjakannya. Padahal menurut immanuel kant akal manusia hanya dapat memahami hal-hal yang dinamakan fenomena. Disamping fenomena terdapat noumena yang mana

\footnotetext{
${ }^{30}$ Lihat ibid., h. 385.

${ }^{31}$ Lihat ibid., h. 386.

32Prof. Rasjidi, putra Yogya kelahiran Kotagede, 20 Mei 1915 pernah belajar di Darul Ulum dan Universitas Kairo pada awal 1930-an. Tahun 1946, ia diangkat menjadi Menteri Agama RI pertama di bawah Kabinet Sutan Syahrir. Jabatan Duta Besar di beberapa negara juga sempat dienyamnya. Gelar doktor diperolehnya dengan predikat 'cumlaude' di Universitas Sorbone, Paris. Hebatnya, Rasjidi menyelesaikan doktornya, saat ia menjabat sebagai anggota perwakilan Indonesia di PBB tahun 1950-an, yang ketika itu bermarkas di Paris. Tahun 1956, ia sempat menyelesaikan disertasinya di Sorbonne di bawah supervisi Prof. Louis Massignon, seorang orientalis terkenal.
} 
akal tidak mungkin mengtahuinya. Untuk mengetahui noumena atau ding an sich, manusia memerlukan etika. Imanuel kant adalah filosof modern yang besar pengaruhnya karena Harun Nasution tidak mempergunakan filsafat Kant maka pahamnya tentang Islam menimbulkan persoalan terus. ${ }^{33}$

Cara pandang dan cara penyajian Harun terhadap agama Islam, memang gaya khas orientalis Barat, yang menempatkan semua agama pada posisi dan fenomena yang sama. Dia, misalnya, menggambarkan proses perkembangan teologi sebagai hasil evolusi, dari dinamisme, animisme, politeisme atau henoteisme, lalu monoteisme, yang dia katakan juga sebagai agama tauhid. Dalam perspektif evolutif seperti ini, monoteisme dipandang bukan sebagai kebenaran final, karena bisa berkembang, dan menuju pada jenis paham keagamaan lainnya, semisal ateisme. Ini adalah konsekuensi logis dari cara berpikir evolutif dalam keagamaan. Padahal, Islam sebagai agama Tauhid bukanlah hasil evolusi pemikiran manusia.Sebab, agama Tauhid berasal dari wahyu Allah, sehingga sejak Nabi Adam sampai Nabi Muhammad, konsep agama Tauhid adalah tetap, dan tidak mengalami evolusi. Barat tentu saja tidak mengenal konsep wahyu dalam tradisi pemikirannya, sehingga mereka menempatkan agama sebagai bagian dari gejala budaya yang tumbuh di tengah masyarakat.

Kata Rasjidi: "Menurut penilaian saya, Harun Nasution kurang kritis dalam menerima kuliah di universitas McGill Islamic studies, di negara-negara Barat, pengaruh orientalisme pada umumnya besar." 34

Dari kritikan Rasjidi tentang harun sangat dipengaruhi oleh Kant. Harun Nasution lebih percaya pada akal manusia yang mau tidak mau sampai pada yang baik. Sebaliknya Rasjidi sesuai dengan Kant, melihat keterbatasan akal dan lebih melihat perlunya wahyu. Walaupun harun tidak sependapat dengan kant bahwa logika tidak dapat membawa kayakinan adanya Tuhan karena konstruksi teologi rasioanal harun sangat kental dengan merafisika skolastikme Islam. Padahal pondasi skolastikisme Islam berupa Aristotelenianisme yang sosiologistis-deduktif, seperti Al-Farabi dan Ibn Rusyd. ${ }^{35}$ Kalau filsafat zaman lampau menekankan pada theoria yaitu untuk memahami dunia maka sekarang yang penting adalah merubah dunia.

Kritik golongan kedua adalah perspektif sejarah Islam. Harun membagi sejarah islam kepada tiga priode yaitu periode klasik, periode pertengahan dan

${ }^{33}$ M.Rasjidi, Koreksi terhadap Prof Harun Nasution(2) ajaran Islam tentang Akal dan Akhlak, dalam suara Muhammadiyah, No.24,65,1985,h.2. simuh serang kali diskusi di IAIN Sunan Kalijaga Yogyakarta sering mengritik harun dari persfektif Kant bahwa pemikiran harun kurang cocok dalam konsep akal.

${ }^{34}$ Catatan Akhir Pekan (CAP) Adian Husaini adalah kerjasama ke-124 Radio Dakta 107 FM dan www.hidayatullah.com

${ }^{35}$ Jan Hendrik Rapar, Pengantar Filsafat, (Yogyakarta: Kanisius,1996),h.102 
periode modern. ${ }^{36}$ Pembagian ini sebenarnya sudah digunakan oleh gurunya Wilfred Cantwell Smith yang mendirikan lembaga studi Islam di Universitas McGill. Periode yang diidealkan Harun adalah priode Islam klasik yang penuh prestasi. Priode klasik ini sebenarnya juga ditunjukkan semenjak zaman Nabi walaupun Harun memulainya pasa tahun 650 yaitu masa Ustman ibn Affan. Periode yang banyak dieksplorasi Harun adalah masa Abbasiyah yang punya garis dengan pemikiran Yunani sedangkan periode Nabi tidak banyak tercover. Pada titik inilah kelemahan Harun.

Tinjauan epistemologi dalam pemikiran Islam terdapat dua corak pemikiran yang dominan. Pemikiran tersebut dipengaruhi oleh pemikiran Yunani. Corak yang pertama adalah pemikiran yang tertuju pada Plato dan Neoplatonik yang lebih cenderung berpegang pada dunia idea yang abstrak intelektualistik historis (spekulasi abstrak) dari pengalaman inderawi manusia untuk memperoleh pengetahuan sejati.corak kedua adalah kecenderungan untuk mengikuti konsep Aristoteles yang menekankan perlunya memanfaatkan inderawi untuk menemukan hukum-hukum dan idea yang bersifat universal. Bagi Aristoteles tanpa pengamatan inderawi manusia tidak bisa menemukan hal yang bersifat intelektual universal (sistematisasi rasional0. Aristoteles dijuluki oleh para filosof Muslim sebagai al-Mu'allim al-awwal, sedangkan Al-Farabi dan Ibn Sina dikategorikan kedua atau ketiga. Islam Rasional adalah pradigma Islam yang dipegaruhi oleh para filosof islam yang berbau yunani karenya untuk sekarang diperlukan pemikiran yang sesuai dengan zaman.

Singkatnya rasionalitas yang dijadikan prinsip dasar memandang realitas mulai digugat. Realitas lebih kompleks dari rasionalitas karena realitas bukanlah ketuhanan yang dapat ditangkap oleh rasionalitas manusia. Olehnya itu, Harun Nasution dianggap terlalu menyederhanakan persoalan bahwa kemuduran Islam tidak bisa hanya dicairkan pada siafat fatalisme Asy'ariah akan tetapi ada variabel lain seperti tekanan struktural pengauasa yang ikut menyebabkan penderitaan masyarakat dalam kebebsan berfikir dan berkreasi.

\section{KESIMPULAN}

Harun Nasution adalah seorang pembaharu pendidikan tinggi Islam di Indonesia, yang kontribusinya terhadap perkembangan pemikiran Islam di Indonesia, adalah hasil dari dialog antara dia dengan lingkungan. Kematangan dalam lapangan pemikiran keagamaan, membuat ide-ide dan gagasan pemikirannya diminati dan ia semakin mapan menempatkan dirinya sebagai seorang pembaharu yang objektif dan kritis, meskipun untuk itu ia harus membayar mahal seperti di tuduh Mu'tazilah, mengacaukan bangunan tradisi pemikiran Islam yang sudah mapan, bahkan dituduh keluar dari agama Islam. Harun dengan sangat cemerlang mengantarkan teori pembangunan melalui pembaharuan teologi.

\footnotetext{
${ }^{36}$ Harun Nasution, Islam Ditinjau dari berbagai Aspeknya, jakarta: UI Press, 2000.h.56
} 
Keberhasilan Harun Nasution dalam mengantarkan doktrin perlunya penafsiran kembali kepada ayat-ayat al-Qur'an sesuai dengan keadaan zaman. Berulang kali Harun menegaskan bahwa ajaran Islam itu banyak dan luas maka siapa saja dapat berenang dalam kolam ajaran Islam yang nisbi tersebut, asal jangan keluar dari padanya. Seorang telah dinyatakan keluar dari Islam apabila ia telah melanggar empat hal yang telah disepakati dalam pemikiran Islamyaitu (1) tidak boleh ada dalam pemikiran Islam yaitu Allah tidak ada (2) tidak boleh ada kesimpulan dalam Islam bahwa al-Qur'an bukan wahyu (3) tidak boleh ada kesimpulan dalam pemikiran Islam bahwa Muhammad bukan Rasul Allah, dan (4) tidak boleh ada kesimpulan dalam pemikiran Islam bahwa hari akhir itu tidak ada. Dalam konteks ini, ukurannya adalah zamannya. Harun Nasution terlihat sangat radikal dan berani, sekaligus sangat toleran. Oleh karena itulah Harun harus ditempatkan sebagai tokoh yang telah berhasil melakukan demokratisasi sikap ilmiah dan independensi berfikir serta mengajarkan bahwa semua orang punya hak suara yang sama.

\section{DAFTAR PUSTAKA}

Harun Nasution, Islam Rasional: Gagasan dan Pemikiran (Cet.IV; Bandung: Mizan, 1996).

Harun Nasution, Akal dan Wahyu dalam Islam (Jakarta: UI-Press, 1983).

Harun Nasution, "Ijtihad Sumber Ketiga Ajaran Islam", dalam Haidar Baqir dan Syafiq Basri (ed), Ijtihad dalam Sorotan (Cet. I; Bandung: Mizan, 1988).

Harun Nasution, Teologi Islam, Alira-aliran Sejarah Analisa Perbandingan, Jakarta: UI-Press, 2002.

Harun Nasution, Islam Ditinjau dari Berbagai Aspeknya (Cet.VI; Jakarta: UI-Press, 1986), Jilid II.

Jalaluddin Rahman, Islam dalam Perspektif Pemikiran Kontemporer (Cet.I; Ujungpandang: PT. Umitoha Ukhuwah Grafika, 1997).

Jan Hendrik Rapar, Pengantar Filsafat, (Yogyakarta: Kanisius,1996).

Rasjidi, H>M, Koreksi Terhadap Harun Nasution tentang Islam Ditinjau dari Berbagai Aspeknya, Jakarta: Bulan Bintang, 1983.

Said Aqil al Munawwar, Membangun Tradisi Kajian Islam: Mengikuti Jejak Harun Nasution. dalam Abdul Halim (ed) Teologi Islam Rasional, Apresiasi terhadap Wacana dan Praksis Nasution (Jakarta: Ciputat Press, 2001).

Zain Uchrowi dan Ahmadie Thaha, "Menyeru Pemikiran Rasional Mu'tazilah", dalam dalam Aqib Suminto, , Refleksi Pembaharuan Pemikiran Islam: 70 Tahun Harun Nasution (Cet.I; Jakarta: Lembaga Studi dan Filsafat, 198 
Yusril Ihza Mahendra, Islam dan Masalah Kenegaraan. dalam Abdul Halim (ed). Teologi Islam Rasional. Apresiasi terhadap Wacana dan Praksis Harun Nasution (Jakarta: Ciputat Press, Cetakan I, 2001). 